DOI: $10.19195 / 2084-5065.44 .3$

\title{
Application of capillary electrophoresis in the analysis of coloring matter on paper
}

\author{
Malgorzata Król \\ Laboratory for Forensic Chemistry, Department of Analytical Chemistry \\ Faculty of Chemistry, Jagiellonian University in Krakow, Poland
}

The document, within the meaning of art. $115 \S 14$ of the Penal Code, is any object or stored information carrier, which is related to specific rights, or that due to the content contained therein is proof of the law, the legal relationship or circumstance which has legal significance [1]. In addition to the above definition there are many others, ranging from very general stating that the document is any object with a record of events, thoughts or opinions recorded in any way [2], and ending with a narrow classical notion of a document as transmission of a written declaration of intent in the form of graphic characters (handwritten or printed) on paper or other substrate [3], dated and signed by [4]. It should be noted that the legal definition of term "document" has been extended through the context of the use of this term in relation to acts of counterfeiting — creating it with the intention of deceiving [5]. The document is therefore also an object that in the intention of the perpetrators is to become a document that was clearly stated by the Supreme Court in 1993 [6].

A wide variety of writing and printing tools with very different kinds of coloring matter (ballpoint pen, stamp pad or printing inks as well as toners) can be used for the document preparation [7]. So great variety of writing tools and the spread of computer equipment and office printing (digital printing, color printers and photocopiers), led to a significant increase in number of 
crimes against documents [8]. Moreover, due to the increasingly better quality of available materials and equipment, forgeries are becoming more perfect and more professional and concern every aspect of life and therefore a very broad group of objects with different levels of security. The type and nature of forged documents are related to the objective of the perpetrators. They can be banknotes and other legal tenders, checks, bank documents, documents confirming identity and other documents, such as wills, commercial contracts, medical records, bills, insurance papers, and many similar. The subject of expertise may be also, often anonymous, threatening or ransom demanding letters, notes with warnings of terrorist attacks [9], as well as other suspicious documents with forged signatures, stamps or seals [2].

The specificity of forensic examination in which the questioned document is primarily the evidence in a court case, requires special treatment and the use of methods that are non-destructive and not changing the original state of the document. Thus, the basic analysis using noninvasive optical and microscopic methods are applied first. If their results are not sufficiently unambiguous and the authenticity of the document is still questionable, there is a need to conduct destructive tests. In this case, the consent of the authority issuing the decision is necessary.

The destructive methods used for chemical analysis (discrimination and/or identification) of coloring matter deposited on the paper are as varied as the examined samples. Among them it can be distinguished: spectroscopic methods (UV-Vis [10], FTIR [11] and Raman [12], XRF, SEM [3], ICP-AES [13]), mass spectrometry [14-16], chromatographic methods (TLC [17], HPLC [18], GC [19]) and electrophoretic ones (CE) [20-23].

CE opens up wide possibilities for various analytical applications, which are mainly due to its numerous advantages, the diversity of its modes and the compatibility with different detection systems. This study focuses on discussing two modes of CE: capillary zone electrophoresis (CZE) and micellar electrokinetic capillary chromatography (MECC) [24, 25]. The advantages of these modes differ mainly in separation mechanism, include the minimum sample requirement (minor damage to the document), the ability to simultaneous analyses of a variety of chemical substances (e.g. ionic and nonionic, hydrophobic and hydrophilic), low cost of single analysis, low reagent consumption, small amount of chemical waste.

The CE detection systems can use different physicochemical properties of separated particles, i.e. spectrophotometric absorption detection, laser in- 
duced fluorescence or mass spectrometry. Information provided by mentioned detection are analytically valuable and characterized by a high level of credibility, they can be complementary to each other. Using three mentioned systems information about substances exhibiting absorption, fluorescence and about molecular mass of analyzed compound can be received.

In the Laboratory for Forensic Chemistry many different coloring matters were examined, including ballpoint, fountain pen, gel and stamp pad inks in the most popular colors as well as a large group of branded and off-brand printing inks. For this purpose, the PA 800 plus Pharmaceutical Analysis System (Beckman-Coulter, USA) with a diode array (DAD), laser induced fluorescence (LIF) and mass spectrometry detector microTOF II (Bruker, Germany) was applied.

Figure 1 shows the results obtained with DAD - a device enabling a quantitative measurement of the transmission of radiation through the sample. Electropherograms (the detector signal vs. migration time) obtained for extracts of green stamp inks were compared. The peak positions, i.e. migration times corresponding to the peak maxima, for both dyes and other ink components are considered. Different electrophoretic profiles obtained for the two analyzed samples indicate a high probability that these samples are different. In some cases, shape of the peak and the proportions of the main peaks (relatively to each other) should also be taken into account. In presented example, all 9 inks revealed different electrophoretic profile, thus they can be considered as different.

Second example presented in Figure 2 is also the result of CE-DAD analysis. A cursory analysis of the obtained electropherograms - one for extract from questioned postage stamp and a second for ink from our database (a mixture of Yellow, Magenta and Cyan ink from Business Inkjet 1200 Hewlett-Packard printer) could lead us to the conclusion that these inks are different. However, having some experience and knowledge about fragment of postage stamp from which the analyzed material was taken (red atom), the expert can prove that the questioned stamp was printed with the use of Business Inkjet 1200 printer or any compatible with the same type of ink cartridge. The red color is formed during printing by mixing the two inks Magenta and Yellow, and the peaks coming just from these components are also visible in the electropherogram shown in Figure 2a (apart from the paper peak marked with 'p'). So, according to the results of CE-DAD analysis the group identification of inks is possible. 


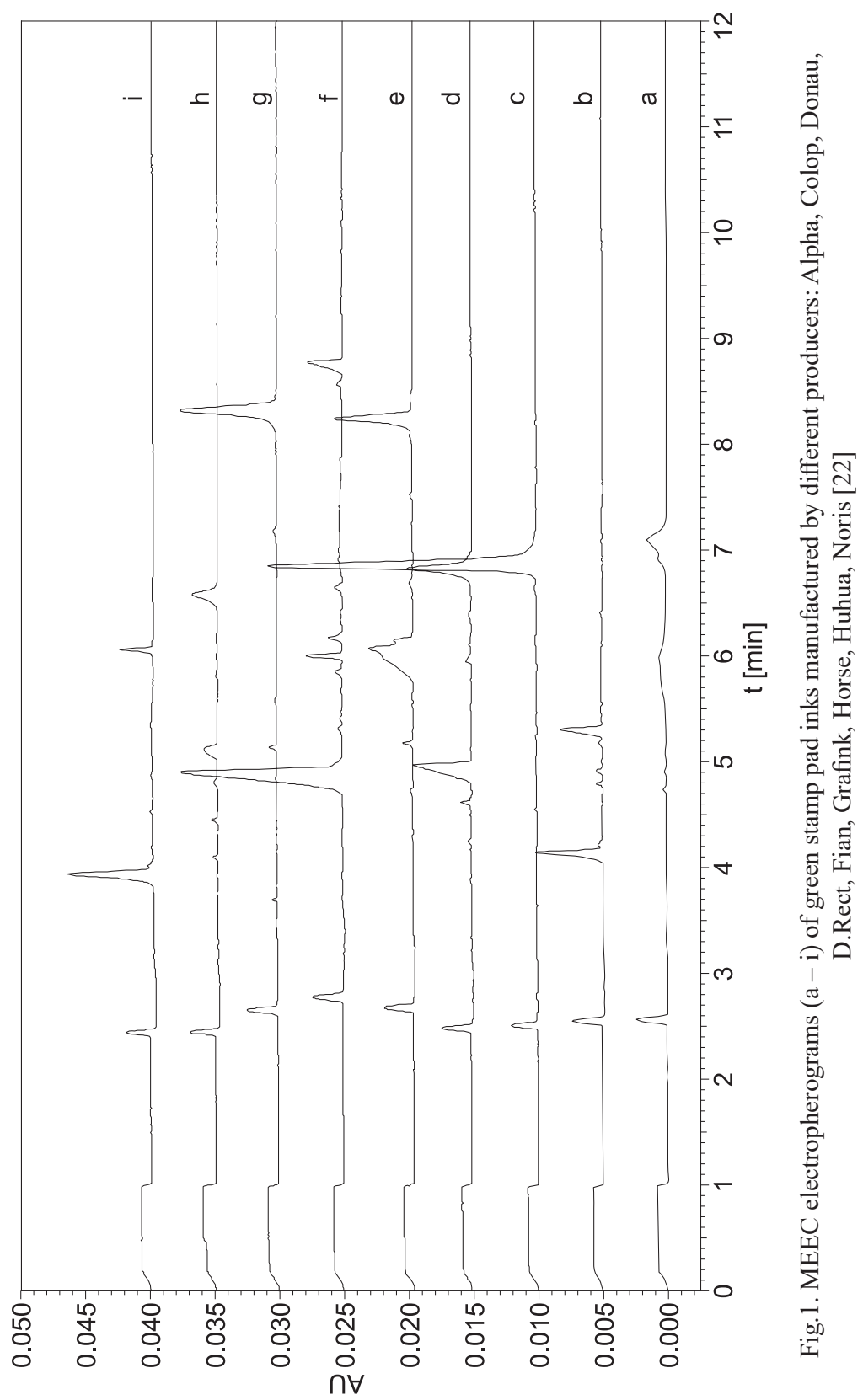

Nowa Kodyfikacja Prawa Karnego 44, 2017

(C) for this edition by CNS 


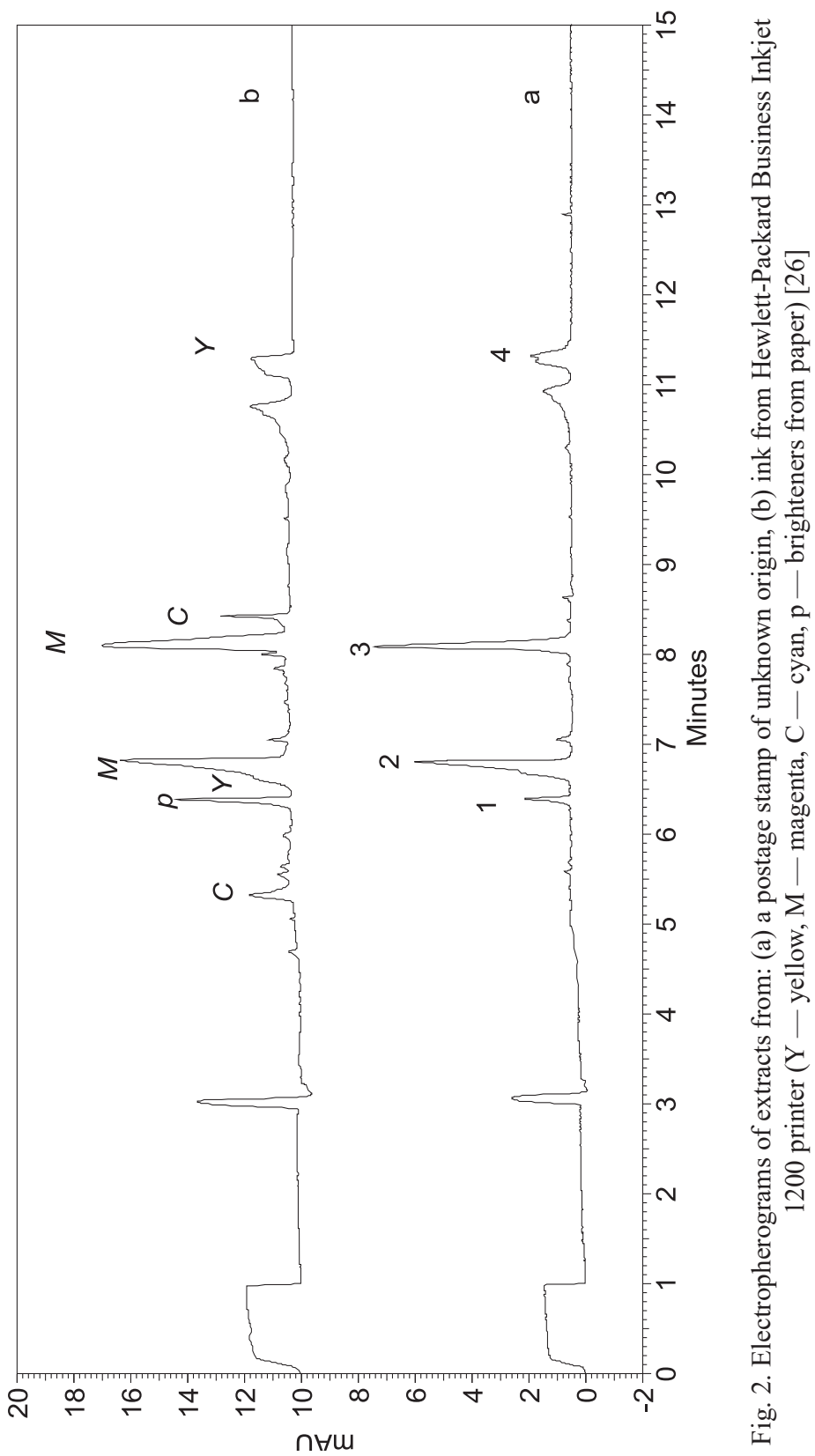

Nowa Kodyfikacja Prawa Karnego 44, 2017

(C) for this edition by CNS 
In case of laser induced fluorescence detection the individual components of the separated mixture are detected when they exhibit fluorescence i.e. emission of radiation after previous excitation. Figure 3 summarizes the electrophoretic profiles of three red writing inks. It can be seen the peaks occur at the same migration times which means that in the tested inks are the same components. On the other hand, there are fragments where very clear differences can be observed (10-11 min). Thus, examined inks are considered to be different with high probability.

And another example of the possibilities offered by methods developed in our laboratory is presented in Figure 4. Three inks extracted from printouts from three models of HP printers: Deskjet Ink Advantage 3525, Officejet Pro 8600 Plus, and Deskjet Ink Advantage 2060 (compatible with different type of ink cartridge) were analyzed. In this case, the situation is similar to the previous one; peaks occurring at the same migration time indicate that Hewlett-Packard uses the same components for the production of inks. Nevertheless, on the basis of the whole electrophoretic profiles the examined inks should be regarded as different.

Unfortunately, there are also cases in which the results obtained from the CE-LIF analysis do not provide sufficient information to enable for differentiation of the examined inks. This was in the case of a group of three red stamp pad inks (D. Rect, Fian and Office Point) produced independently by different companies. As can be seen in Figure 5, the obtained results are very difficult to interpretation because there is only one peak appeared in the electropherograms. One can observe small shifts in peak migration times, but on the basis of this small difference no categorical conclusion about the lack of similarity of analyzed inks can be drawn.

Similar indecisive results were obtained using spectrophotometric detection for blue stamp pad inks from different manufacturers (Fig. 6). This is due to the fact that stamp inks are less complicated mixtures than inkjet printer inks and only one major peak coming from main dye is usually visible in the electropherogram. Working with diode array detector, the analyst has the possibility to verify an UV-Vis spectrum of a dye. However, in presented example even comparing of dye spectra did not allowed for differentiation of all nine analyzed samples. 


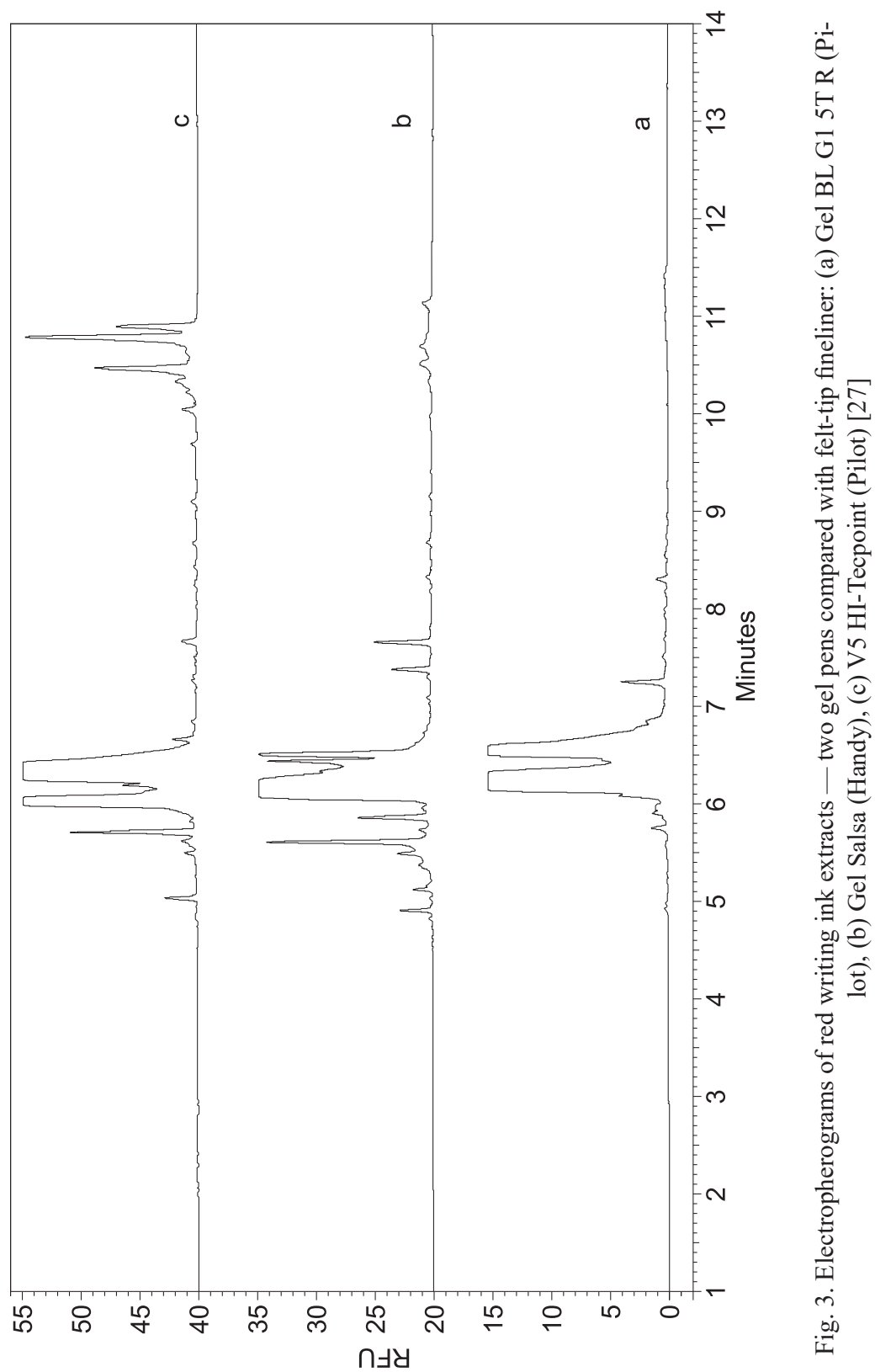

Nowa Kodyfikacja Prawa Karnego 44, 2017

(C) for this edition by CNS 


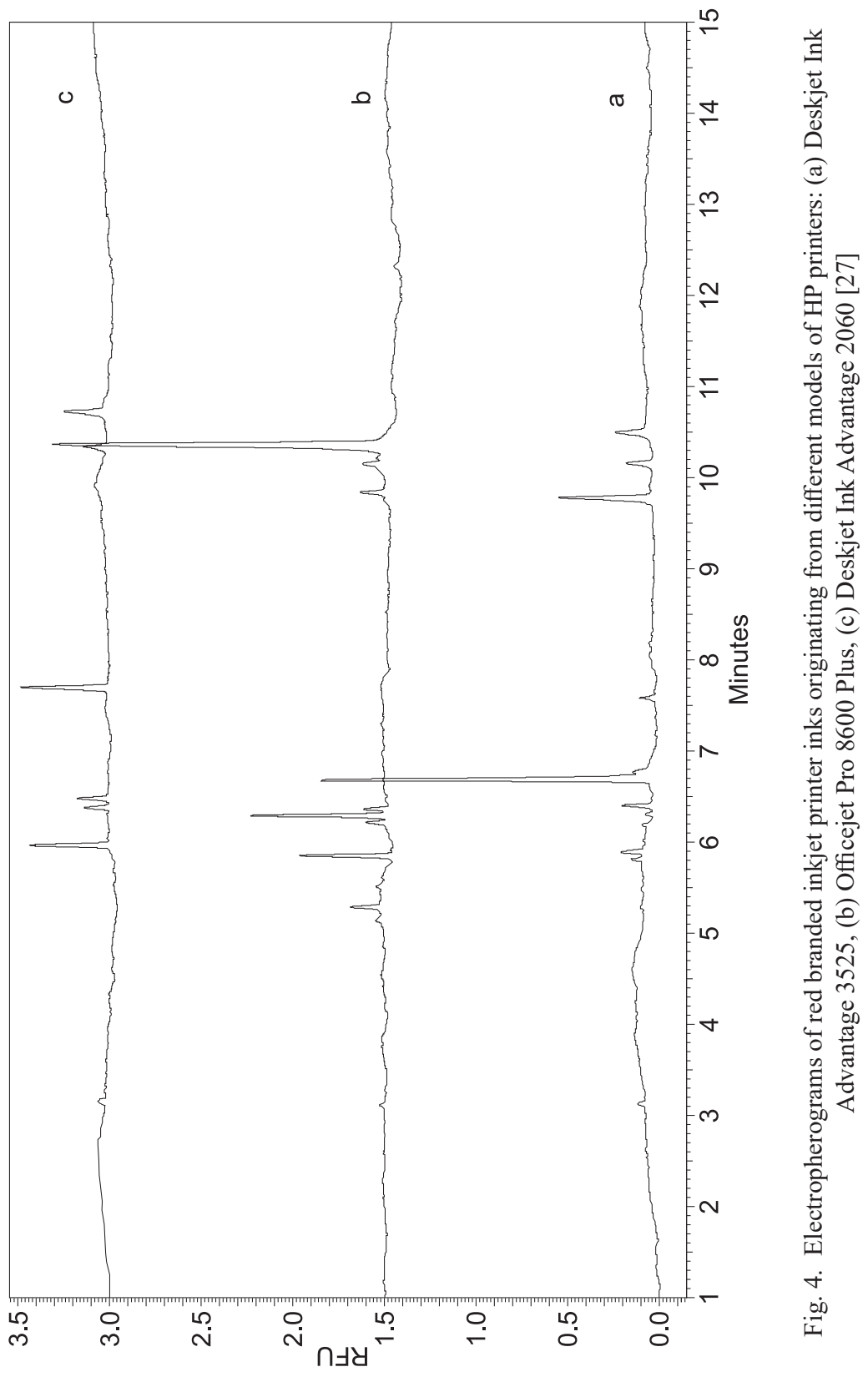

Nowa Kodyfikacja Prawa Karnego 44, 2017

(C) for this edition by CNS 


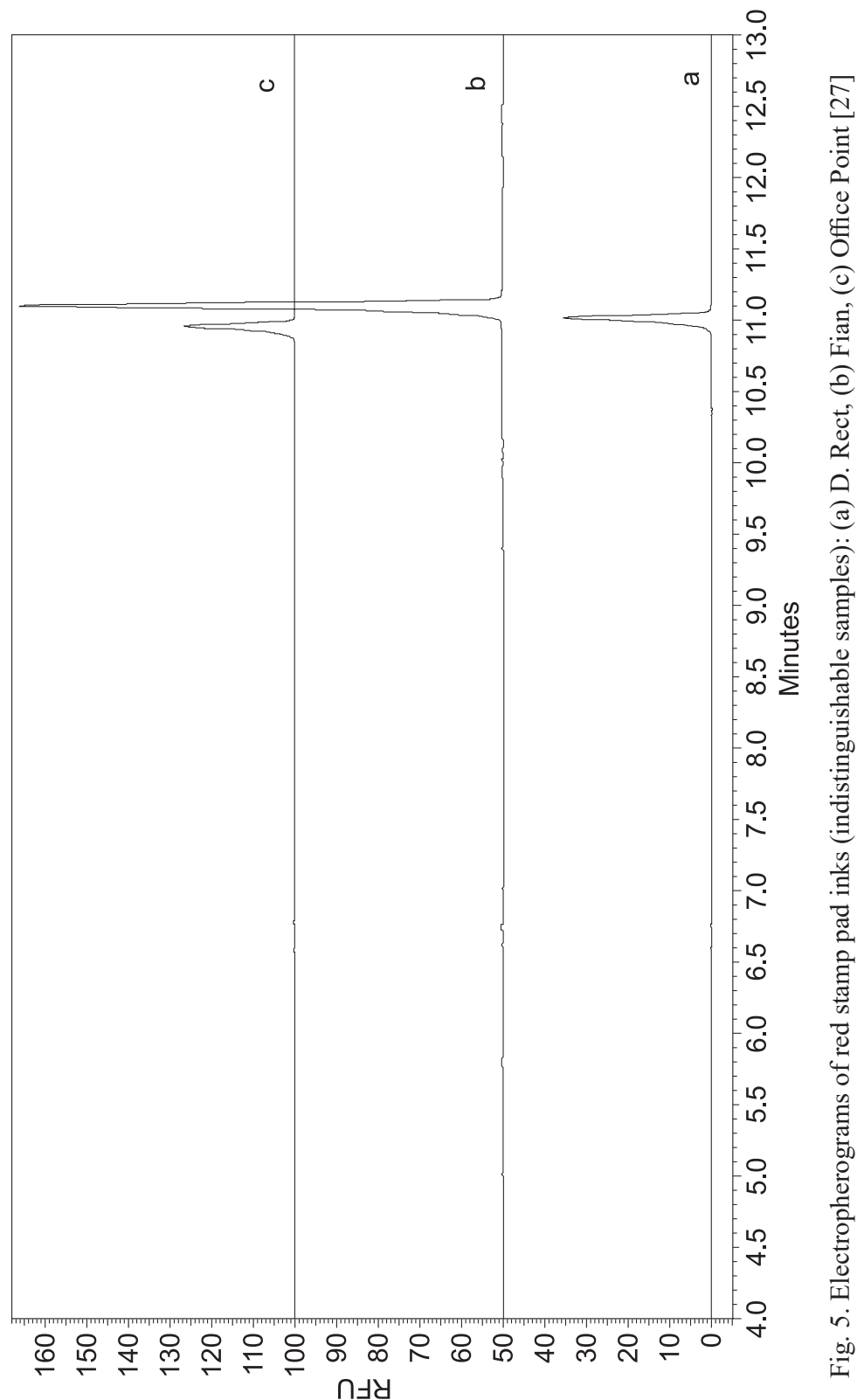

Nowa Kodyfikacja Prawa Karnego 44, 2017

(C) for this edition by CNS 


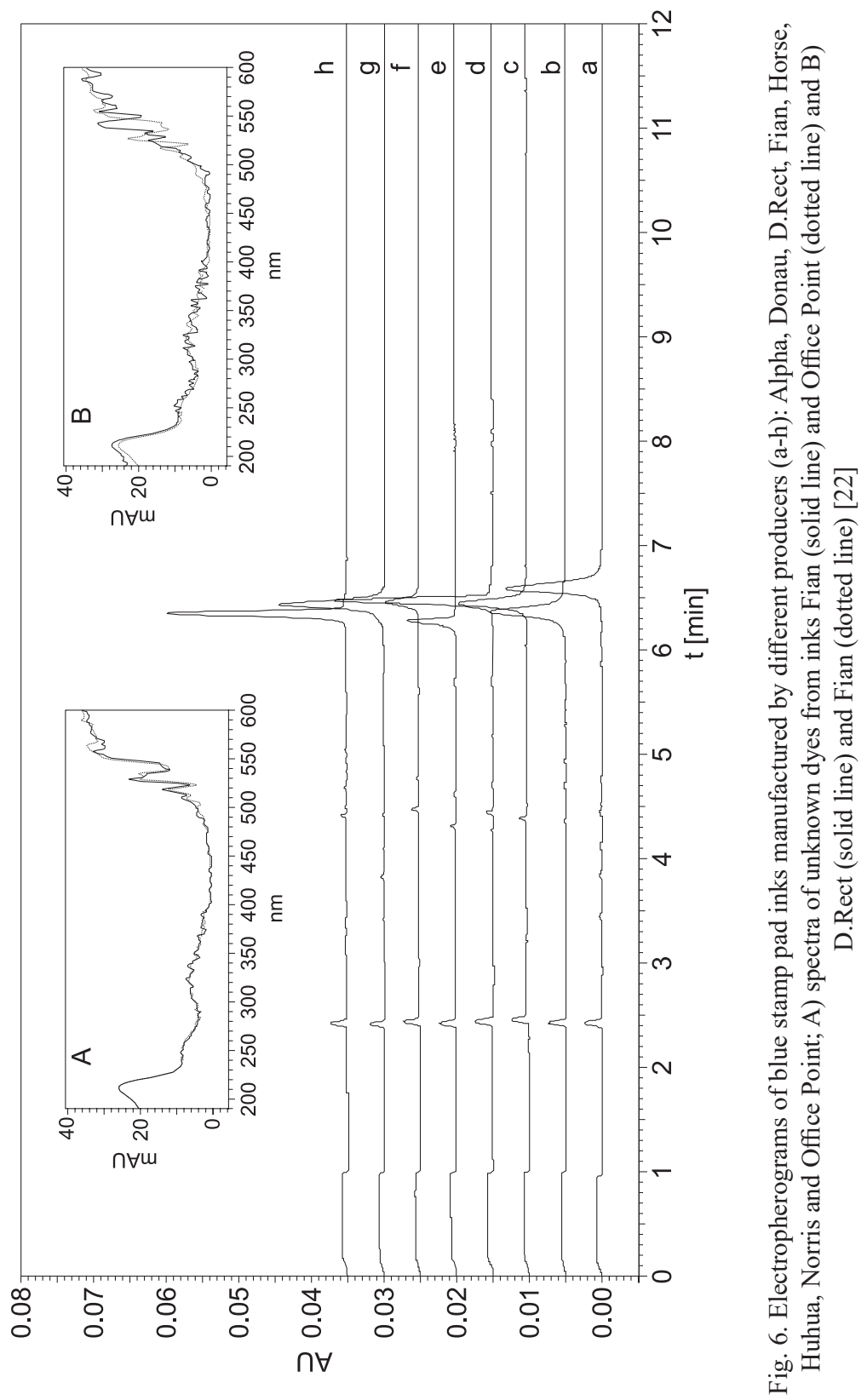

Nowa Kodyfikacja Prawa Karnego 44, 2017

(C) for this edition by CNS 
In such cases, a very helpful tool is an another method developed in the Laboratory for Forensic Chemistry with the use of capillary electrophoresis coupled with mass spectrometer. It provides information on the molar masses of the compounds contained in the sample, and in turn, the identification of their structure is possible. Figure 7 summarizes the results obtained for the extract from the Alpha ink. The mass spectrum is the dependence of the mass distribution of the compounds that reach the detector at a given time on the number of counts (i.e. actually on the concentration of a particular component). Using this type of detection two kinds of information can be received about the component that give the possibility of differentiation - the migration time and the ratio of compound mass to its charge. As with the previous types of detection, extraction of the coloring matter is also required here. Thus, this is a destructive method, but very helpful in determining the composition of various kind of inks. Based on mass to charge ratio, neutral molecules, cations, anions, molecules with multiple charges, and both basic and acidic dyes can be identified.

Therefore, the mass spectra of indistinguishable inks analyzed by the previously presented methods (CE-DAD and CE-LIF) were recorded and compared (Fig. 8). It turned out that after excluding the peaks coming from the extractant, background electrolyte and sheath liquid, it is possible to find differentiating peaks in the spectra — the peak marked by circle in Figure 8A originating from Victoria Blue B dye. Often, at about migration time of neutral components characteristic mass spectrum of the polymer can be found (Fig. 8B marked by ellipse).

Also for the inkjet printer inks the examination yielded the presence of a specific mass spectrum originating from the additive — polymer with different end groups. The mass distribution of mentioned additive, as shown in the Figure 9, is characteristic for each producer of inkjet printer inks.

In conclusion, it should be noticing on the basis of the obtained results that the CE-DAD method shows great applicability, allowing for differentiation of a significant number of black and colored inkjet printer inks and their off-brand substitutes extracted from the paper (from different manufacturers). It has been proved that the laser induced fluorescence detection can provide additional information on samples previously examined by CEDAD. It has been shown that the mass detection improves the discriminating possibilities of $\mathrm{CE}$. It allows the group identification of inks because the 
characteristic mass spectrum (at the migration time of neutral molecules) is deriving from the additive (polymer). Although in this study only the results for writing, stamp and inkjet printer inks were presented, the developed procedures can, of course, be used to various other coloring matters.

\section{Acknowledgements}

The authors gratefully acknowledge the National Science Centre and the Ministry of Science and Higher Education for their financial support (grant no. IP2012025672).

The research was carried out with equipment purchased thanks to the financial support of the European Regional Development Fund within the framework of the Polish Innovation Economy Operational Program (contract no. POIG.02.01.00-12-023/08).

The authors gratefully acknowledge the WILEY publisher for the possibility of using in this chapter three figures (Fig. 3 - Fig.5) from the article:

Małgorzata Król, Klaudia Gondko, Agnieszka Kula, Paweł Kościelniak, Analysis of red inks by micellar electrokinetic capillary chromatography with laser-induced fluorescence detection, Electrophoresis 37 (2016) 372-380,

http://onlinelibrary.wiley.com/doi/10.1002/elps.201500303/abstract

The authors gratefully acknowledge the Elsievier publisher for the possibility of using in this chapter one figure (Fig. 2) from the article:

Małgorzata Szafarska, Renata Wietecha-Posłuszny, Michał Woźniakiewicz, Paweł Kościelniak, Application of capillary electrophoresis to colour inkjet printing inks examination for forensic purpose, Forensic Science International 212 (2011) 78-85,

http://www.sciencedirect.com/science/article/pii/S0379073811002325?via$\% 3$ Dihub

and four figures ( Fig.1 and Fig. 6 - fig. 8) from the article:

Małgorzata Król, Agnieszka Kula, Paweł Kościelniak, Application of MECC-DAD and CZE-MS to examination of color stamp inks for forensic purposes, Forensic Science International 233 (2013) 140-148,

http:/www.sciencedirect.com/science/article/piiS0379073813004143?via$\% 3$ Dihub 


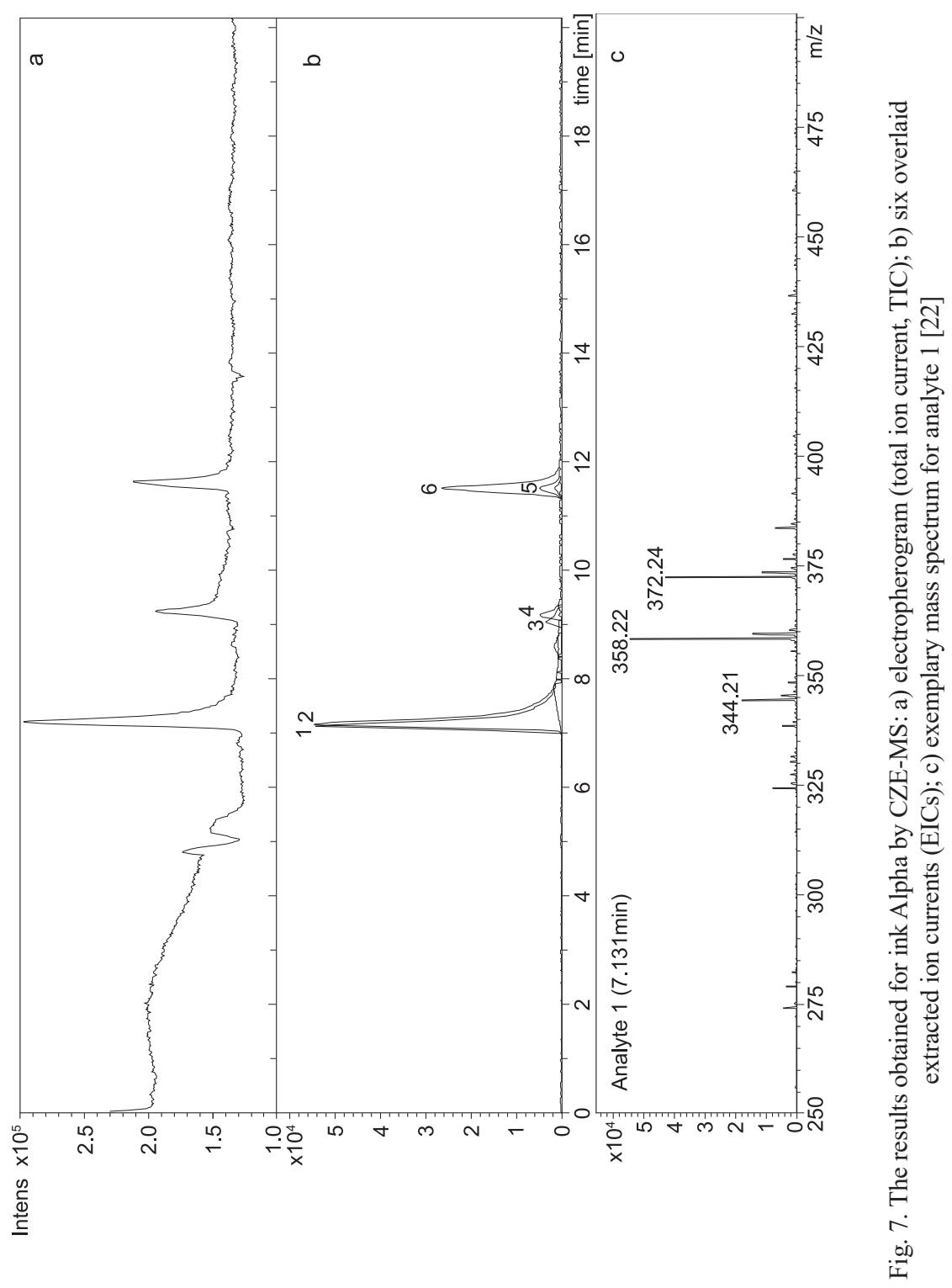

Nowa Kodyfikacja Prawa Karnego 44, 2017

(C) for this edition by CNS 


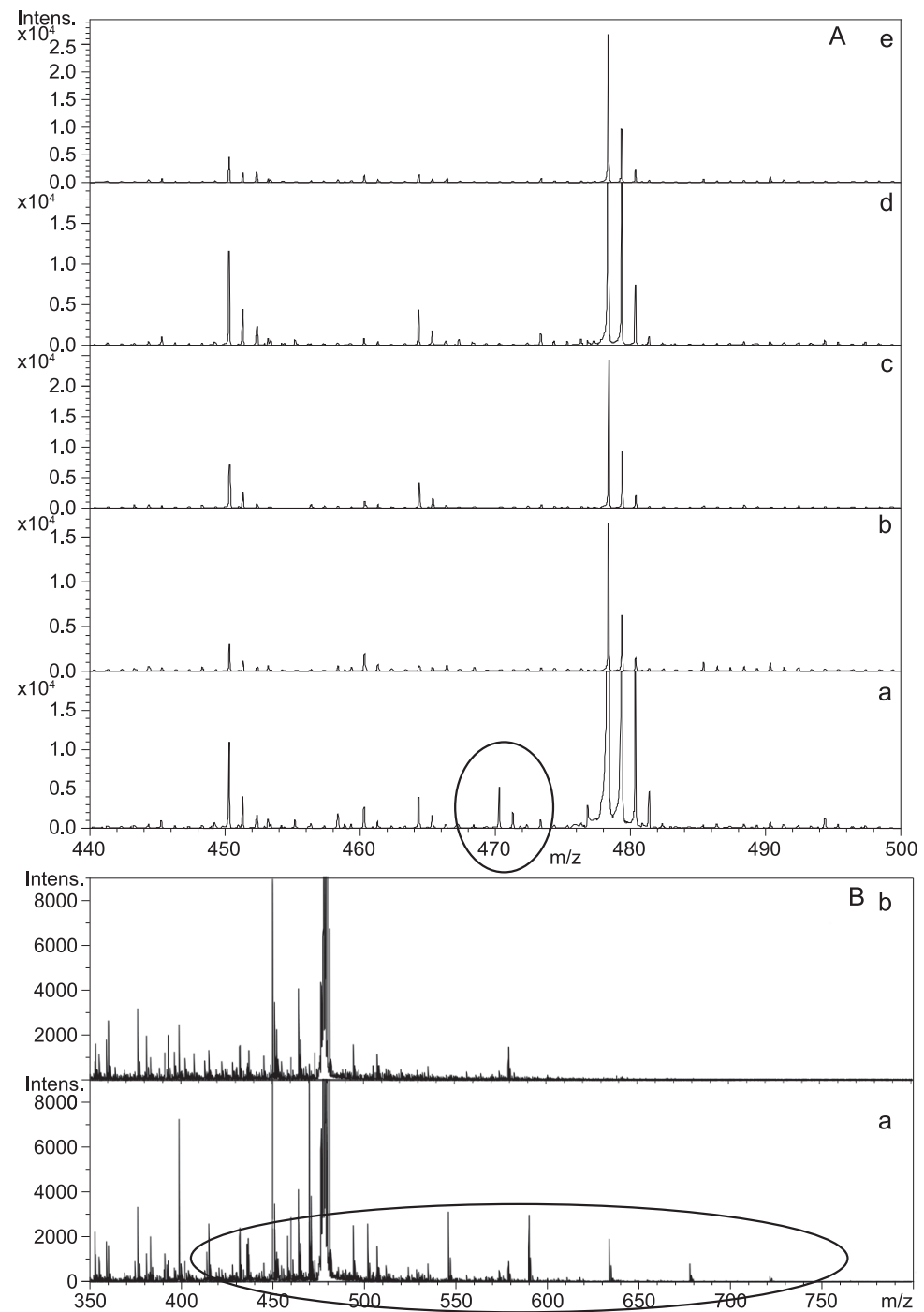

Fig. 8. Mass spectra of blue stamp inks extracted from TIC at peak about: A) 9.5 min (a-e): D.Rect, Fian, Horse, Huhua and Office Point, B) 9.9 min: a) D.Rect and b) Huhua [22] 


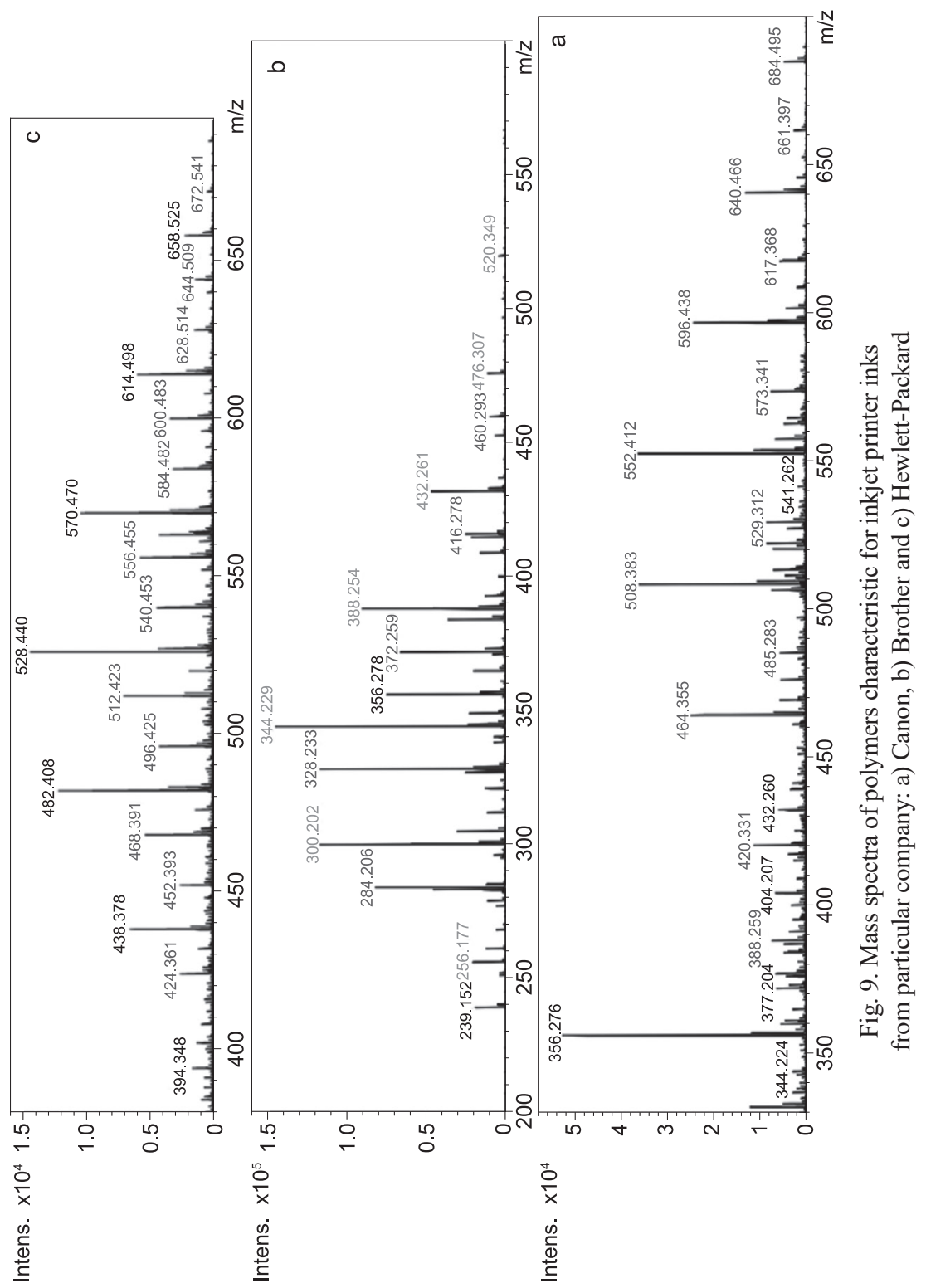

Nowa Kodyfikacja Prawa Karnego 44, 2017

(C) for this edition by CNS 


\section{References}

[1] The act of 18.03.2004 (after amendment), the Penal Code.

[2] B. Hołyst, Kryminalistyka, Wydawnictwa Prawnicze PWN, Warszawa 1996.

[3] E. Fabiańska, "Ekspertyza dokumentów", [in:] J. Wójcikiewicz [ed.] Ekspertyza sądowa, Zakamycze, Kraków 2002, pp. 167-182.

[4] B.M. Trzcińska, "Badanie materiałów kryjących", [in:] P. Kościelniak, W. Piekoszowski [ed.] Chemia sadowa, Wydawnictwo Instytutu Ekspertyz Sądowych, Kraków 2002, pp. 301-308.

[5] K.K. Kopenhaver, Attorney's Guide to Document Examination, Quorum Books, London 2002.

[6] G. Zapotoczny, "Fałszerstwa dokumentów i nowoczesne zabezpieczenia przed nimi”, [in:] Z zagadnień prawa karnego. Studia Iuridica, t. 46, Wydawnictwo Uniwersytetu Warszawskiego, Warszawa 2006, pp. 327-336.

[7] J. Zięba-Palus, "Podstawy fizykochemii kryminalistycznej”, [in:] P. Kościelniak, W. Piekoszowski [ed.] Chemia sądowa, Wydawnictwo Instytutu Ekspertyz Sądowych, Kraków 2002, pp. 205-247.

[8] M. Gramatyka, "Fałszowanie 'papierów firmowych", [in:] Z. Kegel [ed.] Problematyka dowodu z ekspertyzy dokumentów, t. 1, Katedra Kryminalistyki Wydziału Prawa, Administracji i Ekonomii Uniwersytetu Wrocławskiego, Wrocław 2002, pp. 85-88.

[9] P. Kardas, "Narzędzia analizy językowej w badaniach tekstów pisanych o nieznanym bądź niepewnym autorstwie", [in:] Możliwości badawcze niektórych specyficznych dokumentów, Wydawnictwo Centralnego Laboratorium Kryminalistycznego Komendy Głównej Policji, Warszawa 2002.

[10] N.C. Thanasoulias, N.A. Parisis, N.P. Evmiridis, "Multivariate chemometrics for forensic discrimination of blue ball-point pen inks based on their Vis spectra", $F_{O}-$ rensic Science International 138, 2003, pp. 75-84.

[11] B. Trzcińska, "Writing materials examination in criminalistic research by FTIR spectroscopy", Journal of Molecular Structure 294, 1993, pp. 259-262.

[12] E. Fabiańska, M. Kunicki, "Analysis of the influence of surface, passage of time and conditions of storage of documents on optical properties and Raman spectra of inks", Problems of Forensic Sciences 67, 2006, pp. 249-254.

[13] A.A. Cantu, "Analytical methods for detecting fraudulent documents", Analytical Chemistry 6, 1991, pp. 847-854.

[14] L. Ng, P. Lafontaine, L. Brazeau, "Ballpoint pen inks: characterization by positive and negative ion-electrospray ionization mass spectrometry for the forensic examination of writing inks”, Journal of Forensic Sciences 47, 2002, pp. 1238-1247.

[15] M. Sakayanagi, J. Kumoro, Y. Konda, K. Watanabe, Y. Harigaya, "Analysis of ballpoint pen inks by field desorption mass spectrometry", Journal of Forensic Sciences 44, 1999, pp. 1204-1214.

[16] J. Siegel, J. Allison, D. Mohr, J. Dunn, "The use of laser desorption/ionization mass spectrometry in the analysis of inks in questioned documents", Talanta 67, 2005, pp. $425-429$.

Nowa Kodyfikacja Prawa Karnego 44, 2017

(C) for this edition by CNS 
[17] N.N. Daéid, Review papers: 2004 to 2007, 15th International Forensic Science Symposium, Centre for Forensic Science, Glasgow 2007.

[18] Y. Liu, J. Yu, M. Xie, Y. Liu, J. Han, T. Jing, "Classification and dating of black gel pen ink by ion-pairing high-performance liquid chromatography”, Journal of Chromatography A 1135, 2006, pp. 57-64.

[19] L. Brazeau, M. Gaudreau, "Ballpoint pen inks: the quantitative analysis of ink solvents on paper by solid-phase microextraction", Journal of Forensic Sciences 52, 2007, pp. 209-215.

[20] J.A. Zlotnick, F.P. Smith, "Chromatographic and electrophoretic approaches in ink analysis”, Journal of Chromatography B 733, 1999, pp. 265-272.

[21] V.N. Aginsky, "Writing media and documents", [in:] R. Smith, M.J. Bogusz [ed.] Handbook of Analytical Separations. Forensic Science, vol. 2, Elsevier 2000, pp. 681-691.

[22] M. Król, A. Kula, P. Kościelniak, "Application of MECC-DAD and CZE-MS to examination of color stamp inks for forensic purposes”, Forensic Science International 233 (2013), pp. 140-148.

[23] A. Kula, M. Król, R. Wietecha-Posłuszny, M. Woźniakiewicz, P. Kościelniak, “Application of CE-MS to examination of black inkjet printing inks for forensic purposes", Talanta 128 (2014), pp. 92-101.

[24] Z. Witkiewicz, Podstawy chromatografii, Wydawnictwa Naukowo-Techniczne, Warszawa 2005.

[25] D. Heiger, "High performance capillary electrophoresis. An introduction", Agilent Technologies 2000.

[26] M. Szafarska, R. Wietecha-Posłuszny, M. Woźniakiewicz, P. Kościelniak, “Application of capillary electrophoresis to colour inkjet printing inks examination for forensic purpose", Forensic Science International 212 (2011), pp. 78-85.

[27] M. Król, K. Gondko, A. Kula, P. Kościelniak, "Analysis of red inks by micellar electrokinetic capillary chromatography with laser-induced fluorescence detection", Electrophoresis 37 (2016), pp. 372-380.

\section{Summary}

Modern law enforcement agencies are constantly struggling with crimes against documents. Due to increasing quality of counterfeit documents and different physicochemical properties of inks, such crimes are becoming harder to detect. This situation obliges forensic laboratories for the development and implementation of testing procedures with the use of some modern techniques of chemical analysis.

CE opens up numerous possibilities for various analytical applications, mainly due to its numerous advantages, the diversity of its modes and the compatibility with different detection systems. This study focuses on discussing two modes of CE: CZE and MECC and three different detection systems: DAD, LIF and MS. By using them information about substances exhibiting absorption, fluorescence and about molecular mass of ana- 
lyzed compound can be received. In the Laboratory for Forensic Chemistry many different coloring matters were examined, including ballpoint, fountain pen, gel and stamp pad inks in most popular colors as well as a large group of branded and off-brand printing inks.

The obtained results showed the great applicability of CE-DAD method. It has been proved that LIF and MS detections improve the discriminating possibilities of CE providing additional information on samples.

Keywords: document, forgery, capillary electrophoresis, analytical chemistry, discrimination. 